\title{
Theo-Pharmaceutical - Parent's Blessing is the Best Theo-Pharmaceutical to Keep their Children both Physically and Mentally Healthy
}

\section{Tapan K Chaudhuri*, Sree Taposh K Chowdhury, Sreemati Bulu R Chowdhury, Tushar K Chowdhury and Tandra R Chaudhuri}

Chowdhury Spiritual Research Center, Hampton, VA, USA

*Corresponding Author: Tapan K Chaudhuri, Professor, Chowdhury Spiritual Research Center, Hampton, VA, USA.

E-mail: tkchaudhuri44@gmail.com

Received: November 25, 2019; Published: November 27, 2019

DOI: $10.31080 /$ ASPS.2019.03.0447

Before the beginning of life every human being was residing in the testicle of their father. Father's wish is the first event that brought every human being to earth.

So for every human being what could be more glorious than respecting and worshipping their father -

- Father is the Heaven, Father is the Religion,

- $\quad$ Father is Worshipable.

The second event in the creation of a new human being is to grow in the mother's womb for nine months.

So, for every human being what could be more glorious than respecting and worshipping their mother -

- Mother and Motherland are more glorious than Heaven.

Therefore, the children should respect and worship their parents to receive their parents' blessings in the form of "Electromagnetic Energy (EME) of their Minds" and parents should constantly shower their blessings on their children. It is these blessings or EME of their mind (Theo-pharmaceuticals) that can keep their children both physically and mentally healthy.
However, parents have to remain constantly in touch with the Almighty God through Worship, Prayer and Meditation in order to acquire and transmit the EME of their minds to their children [1,2].

\section{Bibliography}

1. Chaudhuri TK., et al. "Electromagnetic Energy of the Human Mind". Book published by CreateSpace, USA (2017).

2. Chaudhuri TK., et al. "Physics of God, Universe, Humankind and Peace in Family". Book published by iUniverse, USA (2015).

Volume 3 Issue 12 December 2019 (C) All rights are reserved by Tapan $\mathrm{K}$ Chaudhuri and Sree Taposh K Chowdhury. 